\title{
CORRECTION
}

Open Access

\section{Correction to: A novel adaptable approach for sentiment analysis on big social data}

Imane El Alaoui ${ }^{1} 2^{*} \mathbb{B}$, Youssef Gahi ${ }^{3}$, Rochdi Messoussi ${ }^{1}$, Youness Chaabi ${ }^{1}$, Alexis Todoskoff ${ }^{2}$ and Abdessamad Kobi

*Correspondence: imane.el.alaoui@uit.ac.ma

${ }^{1}$ Laboratoire des Systèmes de Télécommunications et Ingénierie de la Décision, University of Ibn Tofail, Kenitra, Morocco

Full list of author information

is available at the end of the article

\section{Correction to: J Big Data (2018) 5:12}

$$
\text { https://doi.org/10.1186/s40537-018-0120-0 }
$$

The authors note a correction to the article [1]. Table 5 of the original article is incomplete. Few percentage values are missing. This article presents the corrected version of Table 5. 


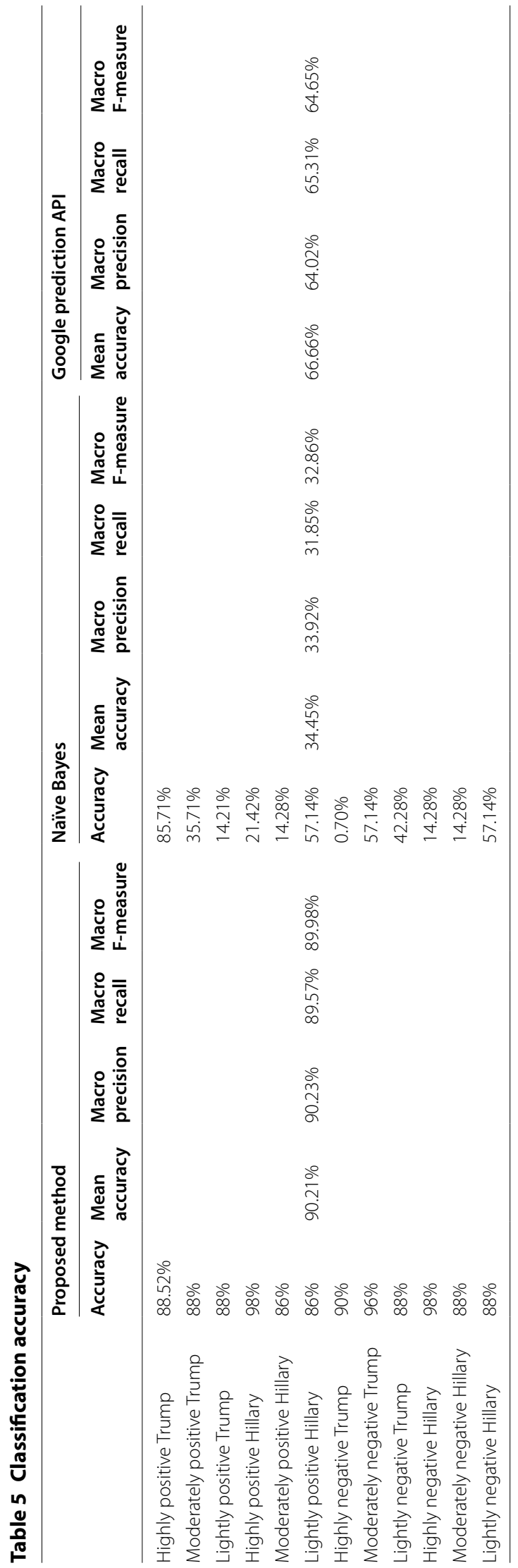




\section{Author details}

${ }^{1}$ Laboratoire des Systèmes de Télécommunications et Ingénierie de la Décision, University of Ibn Tofail, Kenitra, Morocco.

${ }^{2}$ Laboratoire Angevin de Recherche en Ingénierie des Systèmes, University of Angers, Angers, France. ${ }^{3}$ LGS, Ecole

Nationale des Sciences Appliquéees, University of Ibn Tofail, Kenitra, Morocco.

The original article can be found online at https://doi.org/10.1186/s40537-018-0120-0.

Published online: 22 August 2019

\section{Reference}

1. El Alaoui I, Gahi Y, Messoussi R, Chaabi Y, Todoskoff A, Kobi A. A novel adaptable approach for sentiment analysis on big social data. J Big Data. 2018;5:12. https://doi.org/10.1186/s40537-018-0120-0.

\section{Publisher's Note}

Springer Nature remains neutral with regard to jurisdictional claims in published maps and institutional affiliations. 